\title{
To what extent is air freight affected by the Corona virus pandemic?
}

\author{
Soufyane Bouali * ${ }^{\mathbb{D}}$, Selma Douha ${ }^{* *}$, Nadjib Khadri *** \\ * Faculty of Economics, Commerce\& Management Sciences, Sétif 1 University, Algeria \\ soufiane.bouali@univ-setif.dz \\ ** Faculty of Economics, Commerce\& Management Sciences, University of Bordj Bou Arreridj, Algeria \\ *** Faculty of Economics \& Management Sciences, University of Tunis El Manar, Tunisia
}

\section{open 0 actess Co dol}

\section{Article history:}

Received: August 18, 2020

1st Revision: September 16, 2020

Accepted: November 07, 2020

\section{DOI:}

10.14254/jsdtl.2020.5-2.9

\begin{abstract}
Purpose of the paper aims to find out the impact of the COVID-19 pandemic on the global air transport sector (passenger transport, air freight) during the first three months of 2020, and after analyzing the status of the global air transport market from January to March 2020, the study found that the CORONA pandemic has significantly affected this vital sector, where airlines suffered significant losses due to the cancellation of many flights and travel suspensions, in addition to the laying off of many employment and Some of them went bankrupt, while the volume of air freight decreased after global supply chains were shut down as a result of the closure of factories and limited only to the transportation of medical equipment and food supplies in some countries, and the repercussions of this pandemic are expected to be severe on the global economy in the coming years.
\end{abstract}

Keywords: Air Cargo, COVID-19, crisis, Transport.

\section{Introduction}

Air Cargo facilitate international trade and play an important role in the growth and development of the local economy. The quality and efficiency of Air Cargo services can matter for international trade as a weak Cargo infrastructure and operational processes can be a major obstacle to global trade integration (Devlin, \& Yee, 2005). On the contrary, an improved trade related Air Cargo, combined with a liberalized economic environment, can increase trade volume and economies of scale and scope in distribution and production activities (Lakshman et al., 2001).

Crises of all kinds are the most important turning points of the world in various fields, perhaps the most famous of which is the recession crisis of 1929 and the drug crisis of 2008, which caused the bankruptcy of a large number of banks and included the repercussions of the largest economies, but there are health crises such as epidemics and diseases witnessed in the world over the last century such as the Spanish flu 1920 and SARS 200' and the swine flu 2009 and others that killed millions of people, but the repercussions on the economy were somewhat weak.

Corresponding author: Soufyane Bouali

E-mail: soufiane.bouali@univ-setif.dz 
Today, the world is witnessing the most serious epidemic that threatens both humanity and the economy, which has affected most of the world to become a global epidemic (pandemic), this pandemic called the Corona Covid-19 pandemic, this virus appeared in late December 2019 in the Chinese city of Wuhan and spread to various parts of the world, this virus has led to the countries of the world in a period of economic stagnation awaiting its repercussions at the end of the year, and transport of its kind is the activity most affected by this epidemic, especially air transport. Study of the impact of the Corona Covid-19 pandemic on the global air transport sector during the first quarter of 2020; Analysis of the status of the air transport market from January 2020 to April 2020.

This study aims to:

-Highlighting the Corona Covid-19 pandemic.

-Showing the effects of the corona virus on the air transport sector.

- Study the situation of the air transport market during this global crisis.

The importance of this study lies in highlighting the health crisis that the world has been experiencing since the beginning of the year and its economic and social implications, and its side effects on several vital sectors, especially the air transport sector.

\section{Literature Review}

\subsection{The economic shock of the Covid-19 crisis}

if you're worried about the economic toll of the corona virus crisis, you're not alone it's scary there is no clear forecast and each country's experience, will be different here's what we do know a steady flow of money goods services, and the people to make them flow is essential to a healthy economy and that flow is severed right now by life, savings stay-at-home orders recession is inevitable; but what kind of recession it will be and what recovery might look like is still unclear to help imagine (Richardson, 2020) , authors in the world Consulting Group point out that recessions and their recoveries come in various shock, shapes these are determined by how hard a crisis hits the supply side of an economy; That's an economy's inputs capital like machinery factories software labor or workers plus productivity or how we use labor and capital productively, the heart of the supply side is hit the more credit is interrupted meaning less money is injected in the form of loans to businesses and individuals to fuel investment and the more difficult it is for profitability to recoup from best to most exceedingly awful (OECD, 2020).

The COVID-19 pandemic has, with disturbing pace, managed a substantial hit to an effectively frail worldwide economy, which is relied upon to slide into its most profound downturn since the subsequent universal war, notwithstanding phenomenal strategy support. The worldwide downturn would be more profound if nations take more time to manage the pandemic, if money related pressure triggers defaults, or if there are extended impacts on family units and firms (Frédéric Boissay, 2020). Monetary interruptions are probably going to be increasingly extreme and extended in developing business sector and creating economies with bigger residential episodes and more fragile clinical consideration frameworks; more prominent introduction to worldwide overflows through exchange, the travel industry, and product and budgetary markets; more fragile macroeconomic systems; and progressively inescapable familiarity and neediness. Past the current steep financial withdrawal, the pandemic is probably going to leave enduring scars on the worldwide economy by subverting shopper and speculator certainty, human capital, and worldwide worth chains. Being generally an impression of the ongoing dive in worldwide vitality request, low oil costs are probably not going to give a very remarkable lift to worldwide development in the close to term (Sarker Provash Kumer, 2020). While policymakers' prompt needs are to address the wellbeing emergency and moderate the transient monetary misfortunes, the possible long haul outcomes of the pandemic feature the need to compellingly embrace far reaching change projects to improve the essential drivers of financial development, when the emergency lessens (World Bank, 2020). We don't think these are the correct correlations in light of the fact that the two emergencies-the Great Recession and the Great Depression-were basically request stuns. What you do with an interest stun is standard macroeconomic approach, and in any event, permitting certain errors, we found in the reaction to the Great Recession how financial and money related arrangements attempted to lighten an interest stun. (Peterson K Ozili \& Thankom Gopinath Arun, 2020) This is flexibly stun. Here, everything was working 
as expected, however as COVID-19 heightened, bringing thousands and afterward several thousands into the wellbeing framework, most countries chosen to close down the economy. This was on the grounds that administrations disheartened and afterward restricted individuals going to work. Things being what they are, flexibly is the proportion of what we all things considered produce, yet the infection caused an abrupt constriction of the work gracefully. This has then caused lost certainty that brought about an interest stun, as well (Peterson K Ozili, 2020), yet it's an overflow, an aberrant impact because of a key constriction in our capacity to create merchandise and ventures. At the point when you face a gracefully stun, strategies like those utilized during the Great Recession work, however just in containing the optional stun to individuals' certainty, the interest stun. It's essential to react on the financial and fiscal fronts (UNCTAD, 2020).

On the off chance that you need to contrast the flow emergency with something that occurred before, a superior examination is the oil stun and vitality emergency during the 1970s and mid 1980s. The sharp increment in the cost of oil made the creation and transportation of merchandise significantly progressively costly, frustrating profitable limit as is going on this moment (Taddei, 2020).

As markets try to gradually reopen following the pandemic, it is unlikely that we return exactly to the way things were before the virus outbreak. Travel to develop new products was curtailed during the worst phase of the outbreak, leading to delays in product launches. It is probable that travel continues to be restricted in various ways. Immigration for work will be increasingly constrained as governments impose limits on visa grants - often in response to those imposed by others (Frédéric Boissay, 2020).

\subsection{Logistics and transportation: An overview}

we explain in brief about the transport and the logistics industry how this industries works, what are the main components a lot of people have a misconception that transport and the logistics is the same, so they are not the same right, (Bo Feng, Zheyu Jiang \& Fujun Lai, 2019) first we going to differentiate between the logistics and the transport industry what comes in they logistics is generally the complete detailed organization and implementation of a complex operation in the simple terms if you are going to describe what is in the logistics logistics of physical items usually involves the integration of information flow like a material handling production, packaging inventory, transportation warehousing and other security, logistic requires planning, transport isn't just a mode to execute the planning when getting the afraid from one location to the another location clearly there is not the same thing, but the transportation is just Lee is simply the part of logistics when it comes to logistic logistics executives mix makes further decision beyond the mode of transportation in the transportation services include full truckload less (Yu, 2019), than Trade show shipments within a North Africa now we explain, for example a very basic cycle in the transportation (, 2020), so let's start there are total five essential components first shipper second freight broker third transport company fourth receiver and the last consumer first tier is a shipper is also called the exporter or manufacturer he usually shipped a product, also can use a freight broker who can arrange the transport company for him (Mommens, 2019) in this case freight broker responsibility to arrange truck and giving updates to the shipper and receiver till the load gets delivered because he gets a transport company delivers the freight to the receiver and after that it goes to consumer as a transport company business totally depends on shippers and the freight brokers for a transport company shipper and a freight broker whoever plays are the main client so they always try to make them happy with your extraordinary service transport company can get the freight from the freight brokers or straight from the shipper based on their network, now we going to describe in a very brief the different jobs assigned to the different people for instance (Aalok, 2019), we can take an example in a well-established trucking company in the trucking company there are the two kinds of employees first who work inside the office and the second who work outside the office the employees who work inside the office are the accountants dispatchers load brokers custom clearance agents; or other different clerks the employees who work outside the office are the drivers mechanics warehouse laborers they are all involved in the outside office functions the whole process is a part of a supply chain.

\section{Methodology}

The empirical work is based on three main sources of information. Extraordinarily, be forgotten by adapt evidence was imitative distance from the Schedules dataset by OAG (Official Airline Guide), 
which provides information on a diverse number of variables for each scheduled flight, including origin and destination airport, time of departure and arrival, number of seats supplied, aircraft type, and day of operation. We look on all over cosmopolitan proficiency evidence for the shrewd span months of 2020 (January to April) in order to calculate year-on-year changes with respect to the equivalent dates in 2019. We follow the train of basis proficiency observations in this enquiry, subject the sure thing that, for different reasons, many airlines were flying empty aircraft or with very low load factors before grounding most of their fleet. Alternate scrutiny could crack been the accuracy of OAG data sets given the sudden unprecedented market changes (Pere Suau-Sancheza, 2020).

\subsection{The major unknowns}

The saucy major uncertainty was the future development of air freight. On the several operate, miscellaneous orderly lose concentration Covid-19 would progress the process of greater orientation towards cargo roam many airports were already going through as part of the growing importance of ecommerce. Truly, integrated express carriers (e.g., UPS, FedEx, DHL) would be the great winners in this new set of circumstances. Missing, geographic re-orientation of lodge engagement, dialect mayhap anent increased regionalisation, might see a shift away from air to road deliveries in some markets, except in a few key sectors like pharma, technology and perishables. The understudy chubby question mark for experts was future record prices. Some argued saunter prices would undertaking to growth to cover the new scrimp of an industry, meander might be too large, particularly in the segment of business travel. Excess supply could lead to lower ticket prices and that the industry would need to do significant capacity adjustments to match demand levels, which would keep prices at a level similar to the recent past. A handful offer experts that the authentic below-stairs costs of abscond leasing and of fuel (oil price plummeted during the first quarter of 2020) would certainly allow airlines to offer lower ticket prices. If those load points live low, LCCs would become very aggressive in their pricing to stimulate demand. The obese extrinsic connected with is perforce the spurious arrogate appropriate to to lower costs will outweigh the dampening of demand due to lower levels of disposable income and fear of flying (IATA, 2020).

\subsection{Conceptual framework}

The applied structure of this study investigation follows the settled worldwide exchange hypothesis. Right around two centuries prior, the hypothesis of similar bit of leeway dependent on David Riccardo's work (Riccardo, 1817), proposed that nations can take part in commonly gainful exchange with one another and practice their creation in merchandise for which their chance expense of creation (comparative with the other nation) is most reduced. This hypothesis has been summed up and reached out from the underlying two-great setting to a multiproduct setting and multi-nation settings (Dornbusch, 1977).

Given the expanded degrees of exchange of the 20th century between nations with comparative qualities which made it to some degree hard to clarify by relative favorable position, Paul Robin Krugman clarified the examples of global exchange and the territory of financial action in various nations which prompted the improvement of new exchange hypothesis; The Krugman (1979) model has two center components (Kurgman, 1979). The first is that the creation part in every nation is described by monopolistic firms with economies of scale. The second is that utility increments as more variety of an item is accessible for utilization. The ongoing advances in exchange hypothesis is the attention on miniaturized scale establishments and impacts of exchange, that is, the comprehension of operators who settle on choice to take part in universal exchange. In a general equilibrium frame work, Melitz (2003) presents the augmentation of the new exchange hypothesis. Howl (2012) gives a decent audit of the significance of new exchange hypothesis breaking down reciprocal exchange. Blonigen and Wilson (2013) gave a complete survey of exchange speculations, including, the near bit of leeway hypothesis, the new exchange hypothesis and ongoing advances exchange hypothesis. Past writing has broadly tended to the drawn out impact of exchange on financial development and improvement of countries. In spite of the fact that the standard exchange hypothesis and observational written works investigated above, and the past segment has tended to a few issues identifying with exchange and its connectedness to countries financial development and advancement; concentrates exactly inspecting the immediate 
impact of coordinations on global exchange is as yet uncommon. This has likewise compelled the immediate linkage of the discoveries of a few of the examinations to the reasonable system as talked about above. The explanatory structure and examination that follows beneath is relied upon to make some association on the significance of coordinations with the theoretical system. Taking into account the above conversation, the exact model clarifying the impacts of coordinations on exchange is spoken to by condition (Azmat Gani, 2017).

\begin{tabular}{lccccc} 
Table 1: The COVID-19 Crisis \\
Growth forecasts (\%) & $\mathbf{2 0 1 9}$ & \multicolumn{3}{c}{$\mathbf{2 0 2 0}$} & \multicolumn{2}{c}{ 2021 } \\
\cline { 3 - 6 } & & Current & Pre-shock & Current & Pre-shock \\
\hline World economy & 2.9 & -0.4 & 3.2 & 5.6 & 3.4 \\
Advenced économies & 1.7 & -2.0 & 1.5 & 3.5 & 1.6 \\
US & 2.3 & -1.7 & 1.8 & 3.4 & 1.8 \\
Euro area & 1.2 & -3.1 & 1.1 & 4.4 & 1.3 \\
Germany & 0.6 & -3.1 & 0.7 & 4.1 & 1.5 \\
France & 1.2 & -2.7 & 1.4 & 4.5 & 1.5 \\
Italy & 0.2 & -4.6 & 0.5 & 5.0 & 0.7 \\
Spain & 2.0 & -3.6 & 1.5 & 5.7 & 1.5 \\
Portugal & 2.2 & -3.4 & 1.7 & 5.9 & 1.6 \\
Emerging \& developing economies & 3.8 & 0.5 & 4.4 & 6.6 & 4.5 \\
China & 6.1 & 2.5 & 5.5 & 11 & 5.7 \\
\hline
\end{tabular}

Logical expertise is as of now being activated worldwide at max throttle to all the more likely comprehend the clinical systems of COVID-19 spread and to build up a reasonable antibody. The mechanical alternatives for telecommuting, computerized coordination and virtual learning are as of now encountering a totally new push. Simultaneously, the economy is moving towards an emergency circumstance that takes steps to predominate the 2008/2009 budgetary emergency. Organizations and consultants are confronting an emotional test-in keeping up gracefully chains and creation, yet particularly in managing crumbling request. Simultaneously, a blend of strategy gauges for transient monetary adjustment is rising, which again surpasses the extent of crisis estimates taken after the money related emergency. Strategically and institutionally, the state mediates at the national and territorial levels in manners never rehearsed: section bans, bans on occasions and congregations, business terminations and even curfews. The requests on the political administration particularly in open and majority rule social orders are tremendous. This is because of the way that the Corona emergency specifically requires a colossal measure of solidarity. $80 \%$ of the populace, who have just minor medical issues to fear from the infection, show solidarity with $20 \%$ in especially defenseless populace gatherings. The texture of qualities in our social orders is confronting a significant testparticularly if crisis measures are to keep going for quite a while. (Manfred Fischedick \& Uwe Schneidewind, 2020)

\subsection{Data collection}

The source of the Air Cargo data is The International Air Transport Association (IATA), we reiterate here that, in this, we have relied on IATA reports. This is the only source available that we have.

It should be noted that these sample are chosen because of availability of data on all the variables across four-time periods (January February; March and April). It should be further noted that several countries had data available, but had missing data for Air Cargo measures. As such, missing data on Air Cargo measures meant that several countries had to be dropped from the estimation phase. Even though there is a problem of Imprecision IATA data especially during the lean period, it is still a valid data for Reporting.

\section{Findings}

The International Air Transport Association (IATA) discharged information for worldwide airship cargo deface kets in April indicating that request dropped 27.7\% contrasted with a similar period in 
2019 - the most keen fall at any point recorded. All things considered, there was deficient ability to satisfy need because of the loss of gut load procedure on traveler air-plane. (IATA, 2020)

- Global demand, estimated in load ton kilometers (CTKs), fell by $27.7 \%$ in April con-trasted with the earlier year (- 29.5\% for universal markets).

- Global capacity, estimated in accessible payload ton kilometers (ACTKs), shrank by $42 \%$ in April contrasted with the earlier year (- $40.9 \%$ for worldwide markets).

- Belly limit with respect to universal air payload shrank by $75 \%$ in April contrasted with the previous year. This was mostly counterbalanced by a $15 \%$ expansion in limit through extended utilization of vessel airplane.

- The payload load factor (CLF) rose 11.5 rate focuses in April, the biggest increment since following started. The greatness of the ascent proposes that there is critical de-mand for air load which can't be met attributable to the discontinuance of most traveler flights.

"There is a serious limit smash in air freight. Request fell by $27.7 \%$ contrasted with April 2019. However, limit was down $42 \%$ as a result of the sharp cuts in traveler tasks which additionally convey load. The outcome is harming worldwide gracefully chains with longer transportation times and greater expenses. Carriers are sending however much limit as could reasonably be expected, including unique sanction activities and the brief utilization of traveler lodges for load. Governments need to keep on guaranteeing that essential gracefully lines stay open and productive. While many have reacted with speed and lucidity to encourage the development of freight, government formality-especially in Africa and Latin America-is keeping the business from deftly sending airplane to satisfy the needs of the pandemic and the worldwide economy," said Alexandre de Juniac, IATA's Director General and CEO (IATA, 2020).

Deferrals in getting operational grants gave, blockages at the outskirt and lacking ground framework to/from and inside air terminal conditions keep on hampering air freight in coun-attempts in Africa and Latin America. Air payload needs to move proficiently all through the whole flexibly chain to be powerful. IATA urges governments to:

- Accelerate endorsements for freight activities

- Expedite customs freedom for earnestly required clinical supplies

- Ensure there is sufficient staff on the ground and land-based framework to move payl-oad productively

\begin{tabular}{lccccc}
$\begin{array}{l}\text { Table 2: April Regional Performance } \\
\begin{array}{c}\text { April 2020(\% YEAR- } \\
\text { ON-YEAR) }\end{array}\end{array}$ & WORLDSHARE $^{\mathbf{1}}$ & CTK & ACTK & CLF(\%-PT) & CLF(LEVEL) $^{\mathbf{3}}$ \\
\hline International & $100 \%$ & $-27.7 \%$ & $-42.0 \%$ & $11.5 \%$ & $58.0 \%$ \\
Africa & $1.8 \%$ & $-21.7 \%$ & $-38.7 \%$ & $10.5 \%$ & $48.6 \%$ \\
AsiaPasific & $34.6 \%$ & $-31.0 \%$ & $-48.3 \%$ & $17.3 \%$ & $69.1 \%$ \\
Europe & $23.6 \%$ & $-33.7 \%$ & $-48.8 \%$ & $14.8 \%$ & $64.8 \%$ \\
Latin America & $2.8 \%$ & $-43.7 \%$ & $-64.5 \%$ & $20.5 \%$ & $55.4 \%$ \\
Middle East & $13.0 \%$ & $-36.3 \%$ & $-43.4 \%$ & $5.9 \%$ & $52.5 \%$ \\
$\quad$ NorthAmerica & $24.3 \%$ & $-11.5 \%$ & $-26.4 \%$ & $8.2 \%$ & $48.7 \%$ \\
\hline
\end{tabular}

Air cargo traffic tends to be more sensitive to economic growth than passenger demand and also a lead indicator. Already showing negative growth in 2019, cargo contributed only $12 \%$ of world airline revenue last year. However, given air cargo's usual added sensitivity to economic downturns, it is ironic that it is currently proving more robust than passenger traffic. Crucial for keeping supply chains open, particularly for food, pharmaceuticals and other essential sectors, air freight is not subject to the same COVID-19-related restrictions as passengers. Freighters in service are relatively stable compared with passenger aircraft, particularly among widebodies. However, passenger belly space is a massive contributor to cargo capacity. Reduced passenger networks mean that cargo capacity has fallen heavily year-on-year in all regions, but less so than passenger capacity (capa, 2020). 


\section{Chart 01: International belly cargo and freighter capacity growth}

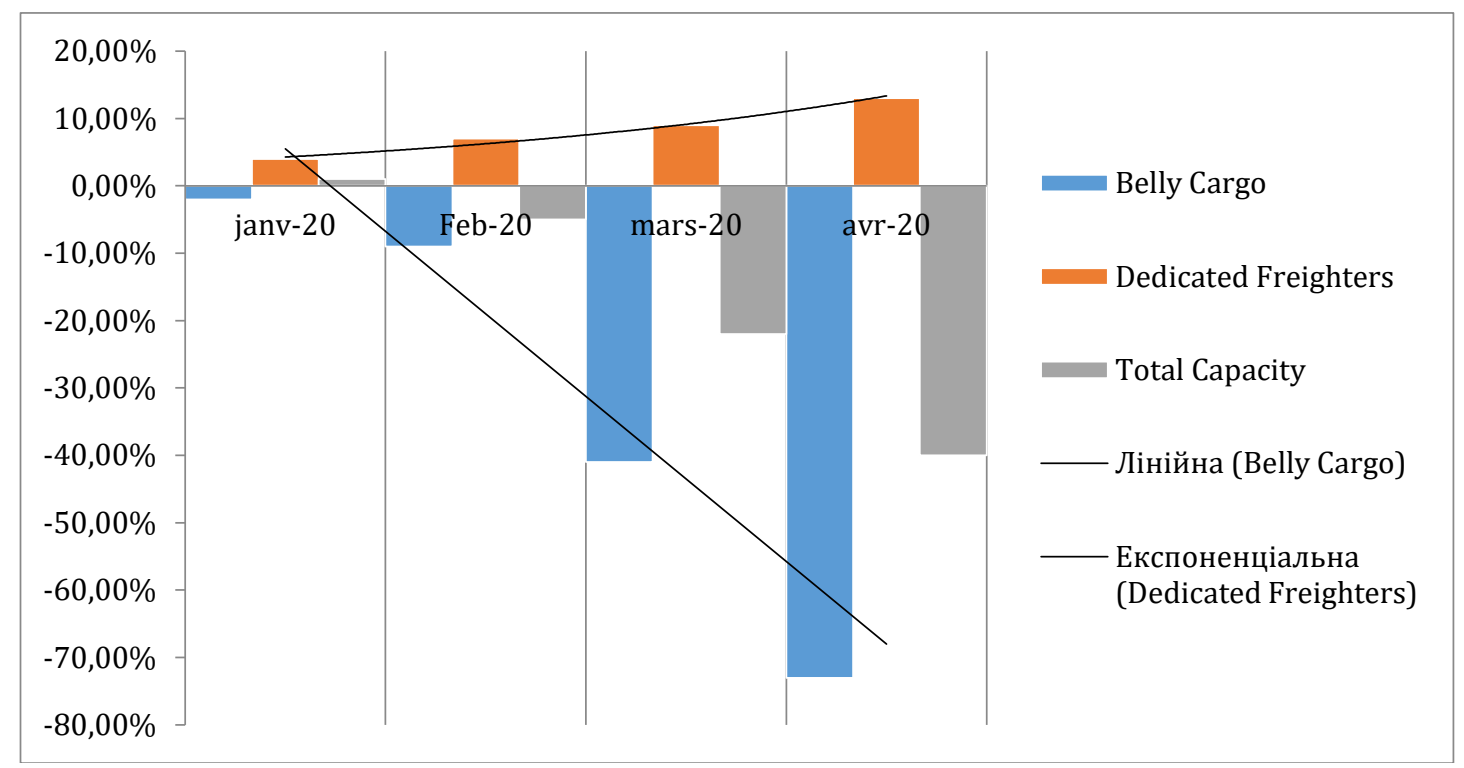

Asia-Pacific airlines saw interest for universal air payload fall by 28.1\% in April 2020, contrasted with a similar period a year sooner. Nonetheless, the enormous Asia-North America showcase recorded to a lesser degree a decay (7.3\%) because of the ascent in development of individual defensive preparement (PPE). Universal limit diminished 42.5\%.

North American carriers transporters revealed a fall in global interest of $20.1 \%$ year-on-year in April. This was the littlest withdrawal everything being equal. While still a noteworthy drop, it stays not exactly the decrease seen at the stature of the Global Financial Crisis in April 2009 (-32.3\%). Global limit diminished $27.7 \%$.

European carriers reported a 33.8\% yearly drop in worldwide freight volumes in April, a lot more honed than the result for March (- 18.5\%). Be that as it may, the huge Europe-Asia advertise recorded to a lesser degree a decrease because of the ascent in development of PPE. Universal limit dewrinkled 46.9\%.

Middle Eastern carriers reported a decline of 36.2\% year-on-year in April, altogether more awful than 14.1\% fall in March. In spite of various transporters in the district keeping up some payload limit, traffic on every single key course was low. Universal limit diminished $42.4 \%$.

Latin American carriers posted the sharpest fall - a 38.9\% year-on-year decrease in international request. Global limit diminished 55.5\%. The COVID-19 emergency is especially trying for carriers situated in Latin America inferable from severe regulation measures and an absence of help from Governments to keep freight moving.

African airlines were less affected by disruptions COVID-19 than different areas in April. They saw year-on-year universal CTKs fall by $20.9 \%$. The little Africa-Asia advertise was the strongest course in April, down just 1.0\%. Universal limit diminished 36.6\% (capa, 2020).

\section{Discussion and implications}

It's a simple supply and demand mismatch. we see, back in March 2020, when COVID-19 reached a pandemic status, almost every airline the world drastically scaled back it's flying. It varied from region to region and airline to airline, but the common trend everywhere was that, if any route got cut, it was almost certainly a long-haul one. In the era of quarantine periods, border closings, and other travel restrictions, there is near-zero demand for the long-haul, international travel, so intercontinental flights were quickly removed from airline schedules. For example, in April 2019, around 500 full circle flights for each day would fly among Europe and the US, be that as it may, in April 2020, that number was decreased to around 80 every day. That represents between $80 \%$ and $90 \%$ reduction. Ignoring airline revenue, you'd think that that would be a loss-free situation, that reduces carbon emissions, many governments are covering the salaries of furloughed workers, it reduces airline expenditure, and nobody's riding in the cabins anyway, but that doesn't consider what rides below the cabin. On nearly 
every intercontinental flight, in the belly hold, among the hundreds of passenger bags, there is cargo. In fact, $45 \%$ of the world's air cargo is carried in this method. Now, the math to ex-plain the supply and demand mismatch is simple. The proportion of cargo carried on passenger aircraft varies from route to route, so $60 \%$ of Western Europe to US air cargo, for example, flies on passenger planes.80\% to $90 \%$ of transatlantic passenger flights are not flying, so about 50\% of air cargo capacity in this market has disappeared in a matter of weeks. The situation is less severe in other markets, but, industry-wide, the overall air cargo capacity reduction was about 23\% in March 2020. So that's the supply figure, but what about demands a huge proportion of the world entered various lockdown scenarios, economic forecasts plummeted. The extent of the financial toll will not be clear for a while, but it is deeply negative.

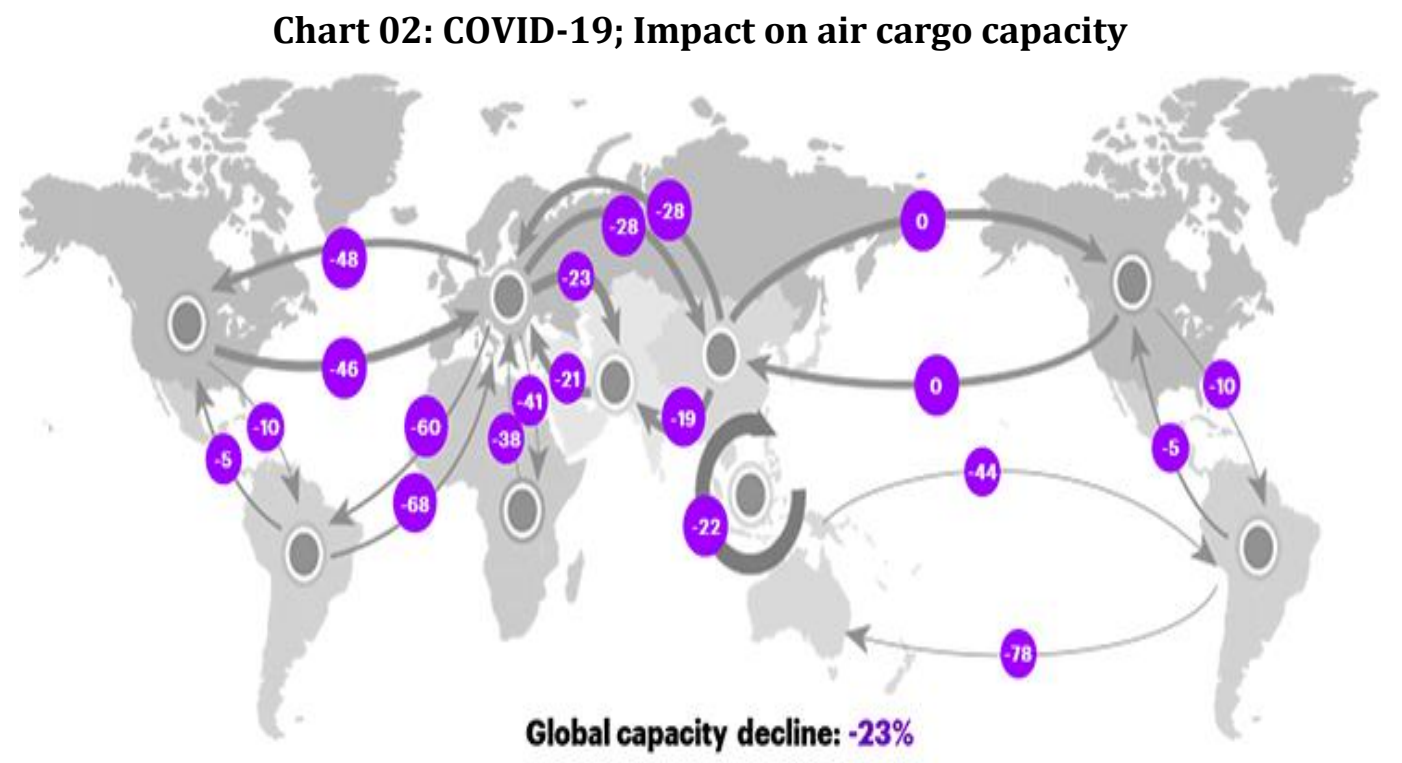

This all influences air cargo demand. On a macro level, consumers are buying less, which means less is shipped, which means companies are buying less, which means less is shipped, which means suppliers are making less, which means less is shipped. On a micro level, different jurisdictions worldwide differ on the exact details of their coronavirus response, but in many places, factories are shut down which means supply chains are cut. So, from an economic perspective, one would predict that demand would almost certainly be down, but like all things in the age of coronavirus, there is another dominant perspective - that of public health. From almost the moment COVID-19 emerged, it became clear that it was a highly infectious virus, which means that a crucial component of the safe treatment of an infected individual is the use of personal protective equipment or PPE. In this context, that means, masks, shields, gowns, and more, which healthcare facilities always stock, but never in the quantity needed to cover nearly universal staff usage fora long period. That means that, in order to reduce the risk of staff exposure, nearly every hospital in the world needed more PPE. Purely by chance, it turns out that the number one medical PPE producing country in the world was also the first country to experience COVID-19 - China. Before the pandemic, the country produced 20 million medical masks per day or about half of the world's supply. By the beginning of March, though, this had already been scaled up to more than 100 million per day. It was at exactly this time when, simultaneously, China's manufacturing industry started to inch back to life and the virus truly took hold of the rest of the world. With how fast COVID-19 ramped up, many hospitals in hotspots like Italy, Spain, and the US were reusing masks and, even with that technique, were down to only days of supply, so they needed supply from China, and other manufacturing hubs, as fast as possible. In the logistics world, "as fast as possible," means air cargo. Thanks to this unprecedented and urgent demand for PPE and other medical supplies, demand for air cargo only dropped by 15\% in March 2020. Considering air cargo capacity dropped by $23 \%$ that means that there was an $8 \%$ gap between supply and demand. In the context of this enormous industry, $8 \%$ is huge, and so the laws of supply and demand followed their course. The cost to transport goods by air spiked, especially in crucial Asia to US and European markets; there is, in any case, one last issue that the air freight world is confronting. Past the transient issue of a lot of interest, the drawn out issue is that this interest won't last. Worldwide air freight request intently follows worldwide monetary 
wellbeing. Each pointer proposes that the economy won't rise up out of the COVID-19 pandemic really near as solid as when it's entered, so there will without a doubt be some moderate months and years for air freight. When earnest interest for clinical supplies facilitates and purchasers have the opportunity to change to more slow types of transportation, the air freight world will more likely than not follow the destiny of its traveler conveying partners. In view of the long-term transformation challenges, it is also important to seize the opportunity to learn further lessons from the Corona crisis (Fischedick \& Schneidewind, 2020). This applies:

1. to the reflection of consumption and behavioral patterns,

2. the reduction of vulnerabilities through globally networked value chains in central production areas

3. the crisis-proof provision of products and services of general interest and basic services, such as goods for the health system.

The collapse of air traffic has resulted in a steep rise in air freight costs, putting further strain on industries that rely on just-intime delivery of foreign-sourced intermediate goods. Supplier delivery times have lengthened considerably and inventories have been depleted

\section{Conclusion}

From the research that has been carried out, it is possible to conclude that the Corona Covid-19 pandemic is one of the most genuine emergencies that has hit the world ever, while deserting huge human misfortunes as far as number of losses and passing's, the world economy has not been saved from its negative consequences for the economies of the significant nations for the most part: The U.S.A, the European Union, China and Japan. Notwithstanding the remainder of different nations less significantly, and maybe the biggest division influenced by this pandemic since its commencement is the vehicle segment when all is said in done and air transport specifically, since the flare-up of the coronavirus in the Chinese city of Wuhan, the administration rushed to force a strategy of absolute control of the city and the revelation of a highly sensitive situation in the nation, which prompted the conclusion of air terminals and the suspension of trips to and from China, trailed by the conclusion of manufacturing plants, causing the disturbance of worldwide gracefully chains.

During the principal set of three of 2020, the world saw the spread of the coronavirus Covid-19 around the globe, which drove the administrations of nations to force a similar arrangement embraced by China from the utilization of isolate, travel limitation, preventive measures and the conclusion of plants, which made the carriers languish overwhelming misfortunes in pay over the undoing of their flights, upkeep costs because of the interference of airplane and full air terminal runways, notwithstanding numerous cutbacks and even pilots. Also, the group, as this emergency prompted the insolvency of certain carriers because of high obligation and the powerlessness of banks to back them.

Concerning airship cargo, its ability has diminished contrasted with earlier years, however the recorded proportions don't influence airship cargo organizations essentially contrasted with traveler bearers, where the pace of air transport of products is low contrasted with the vehicle of merchandise via ocean transport, and a few organizations and nations have restricted to airship cargo by shipping some clinical gear and food supplies between various nations through load planes and even traveler airplane adjusted for the vehicle of merchandise.

At long last, it tends to be said that the repercussions of the Corona Covid-19 pandemic will be serious for the worldwide economy overall, and the air transport segment specifically, which will be reflected in the following not many years.

\section{Citation information}

Bouali, S., Douha, S., \& Khadri, N. (2020). To what extent is air freight affected by the Corona virus pandemic?. Journal of Sustainable Development of Transport and Logistics, 5(2), 98-108. doi:10.14254/jsdtl.2020.5-2.9. 


\section{References}

World Bank. (2020). Global Economic Prospects, June 2020. Washington: DC: World Bank.

Kumar, A., \& Anbanandam, R. (2019). Location selection of multimodal freight terminal under STEEP sustainability. Research in Transportation Business \& Management, 33, 100434.

Gani, A. (2017). The logistics performance effect in international trade. The Asian Journal of Shipping and Logistics, 33(4), 279-288.

Blonigen, B. A. (2013). The growth and pattern of international trade. Maritime Policy and Management, 618-635.

Feng, B., Jiang, Z., \& Lai, F. (2020). Robust approach for air cargo freight forwarder selection under disruption. Annals of Operations Research, 291(1), 339-360.

Capa. (2020, 03 17). COVID-19. By the end of May, most world airlines will be bankrupt. Consulté le 06 15, 2020, sur musicnation: https://centreforaviation.com/analysis/reports/covid-19-by-the-endof-may-most-world-airlines-will-be-bankrupt-517512

Devlin, J., \& Yee, P. (2005). Trade logistics in developing countries: The case of the Middle East and North Africa. World Economy, 28(3), 435-456.

Dornbusch, R., Fischer, S., \& Samuelson, P. A. (1977). Comparative advantage, trade, and payments in a Ricardian model with a continuum of goods. The American Economic Review, 67(5), 823-839.

Boissay, F., Rees, D., \& Rungcharoenkitkul, P. (2020). Dealing with Covid-19: understanding the policy choices (No. 19). Bank for International Settlements.

IATA. (2020). Air Cargo Market Analysis. https://www.iata.org/.

IATA. (2020). Passenger growth slows as COVID-19 impacts the industry.

IATA. International Air Transport Association (2020). COVID-19. Fourth ImpactAssessment.https://www.iata.org/en/iatarepository/publications/economicreports/covid-fourth-impact-assessment/ 13 aout 2020b. URL.

Mommens, K., Brusselaers, N., van Lier, T., \& Macharis, C. (2019). A dynamic approach to measure the impact of freight transport on air quality in cities. Journal of Cleaner Production, 240, 118192.

Krugman, P. R. (1979). Increasing returns, monopolistic competition, and international trade. Journal of international Economics, 9(4), 469-479.

Lakshmanan, T. R, Subramanian, U., Anderson, W., \& Leautier, F. (2001). Integration of Transport and Trade Facilitation. (Washington, DC: World Bank): Directions in Development.

Fischedick, M., \& Schneidewind, U. The Corona crisis and climate protection-keeping long-term goals in mind. In Nachhaltigkeits Management Forum / Sustainability Management Forum (pp. 1-5). Springer. https://doi.org/10.1007/s00550-020-00494-1.

Mazareanu, E. (2020, mars 04). Statista.com. Récupéré sur statista.com: https://www.statista.com/topics/1707/air-transportation/

Melitz, M. J. (2003). The impact of trade on intra-industry reallocations and aggregate industry productivity. Econometrica, 1725-1695.

Tsai, M. C., Merkert, R., \& Wang, J. F. (2020). What drives freight transportation customer loyalty? Diverging marketing approaches for the air freight express industry. Transportation, 1-19.

OECD. (2020). OECD Economic Outlook. Preliminary version.

Suau-Sanchez, P., Voltes-Dorta, A., \& Cugueró-Escofet, N. (2020). An early assessment of the impact of COVID-19 on air transport: Just another crisis or the end of aviation as we know it?. Journal of Transport Geography.

Ozili, P. K., \& Arun, T. (2020). Spillover of COVID-19: impact on the Global Economy. Available at SSRN 3562570.

Ozili, P. K. (2020). COVID-19 in Africa: socioeconomic impact, policy response and opportunities. Policy Response and Opportunities (April 13, 2020). 
Ricardo, D. (1817). On the Principles of Political Economy and Taxation (London: J. Murray). Barney, JBArikan, AM (2001): The Resource-Based View: Origins and Implications, in Blackwell Handbook of Strategic Management, Malden, MA: Blackwell Publisher Inc, 124-188.

Richardson, P. (2020). Weekly Update: Global Coronavirus Impact and Implications. Counterpoint.

Rutherford, S. (2017). The pandemic and its impacts. United-States.

Sarker, P. (2020). COVID Crisis: Fiscal, Monetary and Macro-financial Policy Responses. Monetary and Macro-financial Policy Responses (May 8, 2020).

Yu, S., Yang, Z., \& Zhang, W. (2019). Differential pricing strategies of air freight transport carriers in the spot market. Journal of Air Transport Management, 75, 9-15.

Taddei, F. (2020, 04 16). COVID-19's historic economic impact, in the U.S. and abroad. (j. h. staff, intervieweur)

UNCTAD. (2020). The Covid-19 shock to developing countries: towards a "whatever it takes" programme for the two-thirds of the world's population being left behind. DC: UNCTAD.

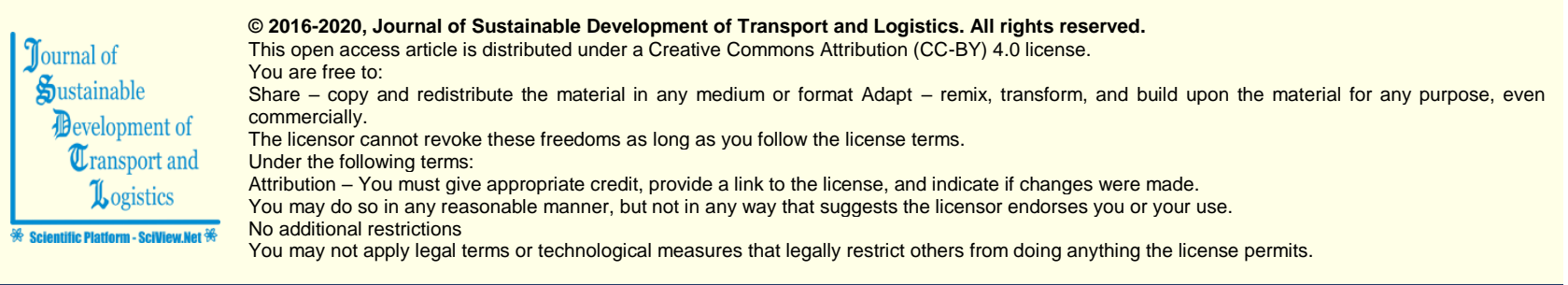

Journal of Sustainable Development of Transport and Logistics (ISSN: 2520-2979) is published by Scientific Publishing House "CSR", Poland, EU and Scientific Publishing House "SciView", Poland, EU

Publishing with JSDTL ensures:

- Immediate, universal access to your article on publication

- High visibility and discoverability via the JSDTL website

- Rapid publication

- Guaranteed legacy preservation of your article

- Discounts and waivers for authors in developing regions

Submit your manuscript to a JSDTL at https://jsdtl.sciview.net/ or submit.jsdt|@sciview.net 